\title{
PENGEMBANGAN KOMIK SEBAGAI MEDIA PEMBELAJARAN AKUNTANSI PADA MATERI AKUN-AKUN PERUSAHAAN DAGANG
}

\section{DEVELOPING COMIC AS A LEARNING MEDIA OF THE MATERIAL OF TRADING COMPANIES'ACCOUNTS}

\author{
Oleh: \\ Fidya Rizka Anggraeni \\ Pendidikan Akuntansi Universitas Negeri Yogyakarta \\ fidyarizka94@gmail.com \\ Sumarsih \\ Jurusan Pendidikan Akuntansi Universitas Negeri Yogyakarta
}

\begin{abstract}
Abstrak
Penelitian ini bertujuan untuk: 1) Mengembangkan komik Akuntansi sebagai media pembelajaran pada materi akun-akun perusahaan dagang untuk siswa SMA kelas XII. 2) Mengetahui kelayakan komik Akuntansi pada materi akun-akun perusahaan dagang sebagai media pembelajaran yang dikembangkan berdasarkan ahli materi, ahli media, dan uji coba pada siswa SMA. Penelitian ini merupakan penelitian pengembangan (R\&D) model pengembangan 4D. Teknik pengumpulan data penelitian ini menggunakan angket. Hasil penelitian adalah: 1) Pengembangan media pembelajaran Akuntansi berbentuk komik sebagai media pembelajaran dapat digunakan 2) Komik Akuntansi sebagai media pembelajaran diperoleh penilaian kelayakan oleh ahli materi dengan rata-rata skor 4,55 dari rentan skor 1-5 termasuk dalam kategori sangat layak dijadikan sebagai media pembelajaran, penilaian kelayakan oleh ahli media dengan rata-rata skor 4,4 dari rentan skor 1-5 termasuk dalam kategori sangat layak dijadikan sebagai media pembelajaran. Penilaian siswa terhadap penilaian media pembelajaran Akuntansi yang telah dikembangkan pada saat uji coba lapangan diperoleh rata-rata skor 4,32 dari rentan skor 1-5 termasuk dalam kategori sangat layak dijadikan media pembelajaran.
\end{abstract}

Kata Kunci: penelitian dan pengembangan, media pembelajaran, komik Akuntansi

\begin{abstract}
This study is intended to: 1) develop accountancy comic as a learning media of the material of trading companies' accounts for XII grader of Senior High School. 2) know the feasibility of accountancy comic of the material of trading companies' accounts as a learning media which is developed based on material expert, media expert and experiment on SHS students. This development research employs several procedures of Research and Development $(R \&$ $D)$ which also adapts the model of $4 D$. The data collecting techniques of this research using questionnaire. The result of the research shows that: 1) development accountancy comic as a learning media can be used 2) accountancy comic as a learning medi has average score 4,55 from vulnerable score 1-5 which is categorized as very suitable to be a learning material on feasibility assessment by the material expert and have average score 4,4 from vulnerable score 1-5 which is categorized as very suitable to be a learning media on feasibility assessment by media expert. Student's opinion of the developed accoutancy learning media's assessment from the field experiment got 4,32 from vulnerable score 1-5 on average score which is categorized as very suitable to be a learning media.
\end{abstract}


Keywords: research and development, learning media, accoutancy comics

\section{PENDAHULUAN}

Kualitas sumber daya manusia merupakan ukuran kemajuan suatu negara. Sumber daya yang cerdas, mandiri, kreatif, inovatif, dan bertanggung jawab dipastikan dapat membangun negara yang maju dan mampu bersaing di level nasional maupun internasional. Orang-orang yang memiliki kemampuan yang lebih juga dapat bertahan dalam menjalani kehidupannya dalam era pasar bebas seperti ini. Salah satu upaya untuk meningkatkan kualitas sumber daya manusia adalah melalui pendidikan. Pendidikan merupakan sebuah usaha yang dilakukan secara sadar oleh pemerintah melalui kegiatan bimbingan, pengajaran, dan/atau latihan yang berlangsung di sekolah dan di luar sekolah sepanjang hayat, untuk mempersiapkan siswa agar dapat memainkan peran dalam berbagai lingkungan kehidupan secara tepat di masa datang.

Pendidikan tidak dapat lepas dari proses belajar mengajar. Proses belajar mengajar terjadi karena adanya interaksi antara seseorang dengan lingkungannya. Interaksi yang terjadi selama proses tersebut akan banyak dipengaruhi oleh lingkungannya yang terdiri dari pendidik, peserta didik, bahan pelajaran, sumber belajar dan media pembelajaran, sarana dan prasarana, serta pihak manajemen lembaga pendidikan tersebut. Dunia pendidikan selalu berupaya untuk mencetak generasi penerus bangsa yang lebih siap untuk menghadapi tantangan dalam kehidupan yang senyatanya yaitu bersaing dengan masyarakat lainnya. Salah satu komponen utama yang mencetak generasi penerus bangsa yang berkualitas adalah seorang pendidik baik di sekolah maupun di lembaga pendidikan non formal lainnya. Pendidik sangat berperan dalam hal tersebut karena pendidik terlibat langsung dalam interaksi yang terjadi dalam proses belajar mengajar. Pendidik yang menyampaikan pengetahuan, nilai dan norma, serta informasi lainnya kepada peserta didiknya. Oleh karena itu, seorang pendidik harus mengetahui metode dan media yang digunakan untuk menyampaikan informasi agar peserta didiknya dapat menyerap dan mengamalkan apa yang disampaikannya.

Salah satu indikator keberhasilan pendidikan adalah terbentuknya individu yang cakap dan mandiri melalui suatu proses belajar. Keberhasilan proses belajar itu sendiri dapat ditandai dengan adanya perubahan tingkah laku individu menuju yang lebih baik.

Akuntansi merupakan salah satu bagian dari cabang ilmu sosial yang cukup unik karena didalamnya dipelajari seni dalam pencatatan keuangan. Masalah yang sering muncul dalam pembelajaran akuntansi salah satunya diakibatkan oleh pembelajaran yang masih terbatas pada buku paket dan power point yang diberikan oleh guru serta peserta didik kurang tertarik terhadap materi yang disampaikan. Pada pembelajaran akuntansi di SMA, yang secara struktur kurikulum masih bergabung dengan mata pelajaran ekonomi, guru cenderung memberikan penanaman konsep secara detail. Pembelajaran lebih didominasi dengan pemberian latihan-latihan soal. Metode pembelajaran ini bertujuan untuk membiasakan siswa mengerjakan soal, sehingga nantinya siswa akan mendapat nilai yang memuaskan pada saat ujian.

Dewasa ini telah dikembangkan berbagai macam media pembelajaran yang secara garis besar dapat digolongkan 
menjadi media grafis, media audio, media visual, dan media audio visual. Dalam proses pembelajaran secara alami siswa lebih banyak menggunakan indera penglihatan yaitu mata. Salah satu media pembelajaran yang akan dikembangkan adalah komik pembelajaran. Komik adalah sebuah media yang menyampaikan cerita dengan visualisasi atau ilustrasi gambar (cerita bergambar). Gambar pada komik berfungsi untuk menguraikan cerita agar pembaca mudah memahami cerita yang disampaikan oleh pengarang.

Penggunaan media pada tahap pembelajaran akan sangat membantu peserta didik menerima materi pembelajaran dan guru mudah menyampaikan materi pembelajaran. Guru juga dituntut untuk lebih kreatif guna meningkatkan mutu pembelajaran dengan perubahan dalam penggunaan media. Guru sebaiknya mulai menyadari pentingnya aspek pengembangan media untuk menunjang proses pembelajaran. Guru dalam melakukan proses pembelajaran menggunakan media berupa alat bantu secara fisik selain itu juga melihat aspek inovasi guru yang berkaitan dengan teknologi dan memikat perhatian pada semua yang terlibat didalam pembelajaran. Media pembelajaran dapat mengatasi kesulitan peserta didik dalam menjalani proses pembelajaran.

Dari hasil observasi awal penelitian pada kelas XII IPS 3 di SMA Negeri 1 Sedayu, pembelajaran yang dilakukan belum menggunakan media komik dan masih menggunakan media power point, buku paket dan soal latihan. Dengan kegiatan mengajar yang cenderung monoton dan satu arah akan mengakibatkan siswa cepat bosan. Hal ini ditandai dengan banyaknyasiswa yang melakukan aktivitas yang tidak terkait dengan materi yang dibahas, seperti mengobrol dan bercanda dengan teman serta beberapa siswatidak berkonsentrasi dalam belajar. Hal tersebut menunjukkan kurangantusiasnya siswa dalam menyimak materi dan kurang inovatifnya guru dalampenyampaian materi.

Berdasarkan permasalahan yang telah diuraikan di atas, maka peneliti akan melakukan penelitian pengembangan dengan judul "Pengembangan Komik sebagai Media Pembelajaran pada Materi Akun-akun Perusahaan Dagang untuk Siswa SMA Kelas XII SMA Negeri 1 Sedayu". Pengembangan komik sebagai media pembelajaran akuntansi ini diharapkan dapat mempermudah siswa untuk memahami konsep-konsep dasar yang dibutuhkan dalam mempelajari akuntansi, mengurangi kejenuhan siswa pada media pembelajaan akuntansi yang kurang variatif dan mendukung siswa SMA Negeri 1 Sedayu untuk belajar mandiri.

\section{METODE PENELITIAN \\ Jenis Penelitian}

Penelitian ini merupakan jenis penelitian berupa penelitian dan pengembangan (Research and Development) yang diadaptasi dari model pengembangan 4D, yaitu define, design, develop, disseminate (Endang Mulyatiningsih 2012: 179-183)

\section{Waktu dan Tempat Penelitian}

Penelitian dilaksanakan di SMA N I Sedayu yang beralamat di Argomulyo, Sedayu, Bantul, Yogyakarta sebagai tempat pelaksanaan uji coba. Pengembangan ini dilaksanakan pada bulan Agustus 2015 sampai dengan Februari 2016, sedangkan penelitian dilaksanakan pada bulan Februari 2016. 


\section{Target/Subjek Penelitian}

Subyek penelitian adalah 32 siswa kelas XII IPS 3 SMA Negeri 1 Sedayu tahun ajaran 2015/2016, sedangkan objek penelitiannya adalah media komik sebagai media pembelajaran Akuntansi pada materi akun-akun perusahaan dagang.

\section{Prosedur Penelitian}

Pengembangan media komik merupakan media grafis yang membutuhkan perancangan produk. Perancangan media meliputi tahap-tahap:

a. Penetapan bentuk media komik, dengan mencari referensi tentang bentuk komik, penokohan dan komik pembelajaran yang telah ada dan penyampaian cerita.

b. Pembuatan storyline dan script digunakan untuk memudahkan pembuatan dan perancangan gambar.

c. Pembuatan gambar dan penokohan yang diupayakan dengan kondisi siswa.

d. Lattering (pengisian teks) dilakukan berdasarkan script dengan memperhatikan bahasa yang mudah dipahami dan mengandung pesang moral baik tersirat maupun tersurat.

e. Penyusunan dan finishing adalah langkah terakhir dalam pembuatan komik dengan melakukan penyusunan halaman judul, kompetensi dasar dan kompetensi inti, isi cerita, daftar pustaka, serta halaman penutup.

Setelah media komik selesai diproduksi pada tahap awal, pengembang media masih perlu menguji kelayakan media untuk digunakan sebagai media pembelajaran. Pengujian pertama dilakukan oleh ahli materi dan ahli media. Hal-hal yang diuji meliputi kualitas materi, kemanfaatan, desain sampul buku, tata letak isi, tipografi dan ilustrasi yang termuat dalam komik. Selama penggunaan media komik dilakukan pengamatan respon peserta didik dalam membaca media. Sesudah membaca komik dilakukan penilaian kelayakan media komik sebagai media pembelajaran oleh siswa SMA yang meliputi penyajian dan kemanfaatan.

Teknik Pengumpulan Data dan Instrumen Penelitian

Penelitian ini menggunakan teknik pengumpulan data berupa kuesioner (angket). Menurut Sugiyono (2015: 199) angket merupakan teknik pengumpulan data yang dilakukan dengan cara member seperangkat pertanyaan atau pernyataan tertulis kepada responden untuk dijawab. Instrumen penelitian angket diisi oleh ahli materi, ahli media, siswa.

\section{Teknik Analisis Data}

Data yang diperoleh dari angket dianalisis secara deskriptif kualitatif dan kuantitatif. Data kualitatif berupa kritik dan saran dari ahli materi, ahli media, dan siswa yang dihimpun untuk memperbaiki Media Pembelajaran Akuntansi berbentuk komik. Analisis Data Kuantitatif Penilaian Media Mengacu pada konversi lima skala yaitu dengan cara menghitung skor rata-rata penilaian produk dengan rumus:

$$
\mathrm{X}=\frac{\sum x}{n}
$$

Keterangan:

$\mathrm{X}=$ skor rata-rata

$\sum \mathrm{X}=$ jumlah skor

$\mathrm{n}=$ jumlah butir

Eko Putro Widoyoko (2011: 237)

\section{HASIL PENELITIAN DAN PEMBAHASAN}

Prosedur yang digunakan dalam pengembangan produk ini merupakan modifikasi dari langkah-langkah penelitian 
dan pengembangan 4D. Penelitian meliputi empat tahap yaitu:

1. Tahap Pendefinisian, dengan melakukan analisis kebutuhan dengan memperhatikan kondisi siswa SMA dengan langkah awal observasi terhadap siswa dan proses pembelajaran serta media pembelajaran yang digunakan. Media pembelajaran yang sering digunakan guru antara lain buku paket, powerpoint, dan menyampaikan materi dengan metode konvensional atau metode ceramah. Proses pembelajaran tersebut memberikan pengaruh pada minat belajar siswa menjadi rendah. Berdasarkan analisis kebutuhan diketahui media pembelajaran yang menarik dan berbeda dari media yang biasanya digunakan seperti buku paket, power point dan LKS diperlukan oleh siswa. Berdasarkan analisis kondisi siswa diketahui merasa bosan dan jenuh ketika menghadapi media pembelajaran yang sama dalam proses pembelajaran. Pengembangan media pembelajaran akuntansi berbentuk komik ini bertujuan untuk mengetahui kelayakan produk komik akuntansi. Dengan adanya media pembelajaran akuntansi berbentuk komik ini siswa dapat memahami konsep-konsep akuntansi dengan mudah. Langkah kedua pengembang melakukan analisis terhadap silabus mata pelajaran Akuntansi untuk menetapkan kompetensi dasar pembelajaran, materi, dan tujuan yang sesuai dengan kurikulum 2013 dan memungkinkan untuk disajikan dalam bentuk komik. Berdasarkan analisis tersebut, diperoleh data bahwa kompetensi dasar dalam penyampaian materi adalah menjelaskan akun-akun perusahaan dagang serta mengklasifikasikan akun-akun perusahaan dagang. Hasil analisis kebutuhan digunakan untuk mendesain produk yang akan dikembangkan.

2. Tahap Perancangan Produk, pengembang melakukan perancangan komik Akuntansi berdasarkan analisis kebutuhan diperoleh rancangan produk sebagai berikut:

a) Komik Akuntansi dengan materi pokok akun-akun pada perusahaan dagang.

b) Komik Akuntansi dengan kompetensi dasar menjelaskan akun-akun perusahaan dagang serta mengklasifikasikan akun-akun perusahaan dagang

c) Alur cerita komik merupakan peristiwa yang terjadi di dalam kelas.

d) Karakter komik dibuat dalam versi kartun yang lucu.

e) Dicetak berwarna dalam bentuk buku dengan kertas berukuran A5.

f) Komik Akuntansi dapat digunakan sebagai media pembelajaran baik di dalam kelas maupun di luar kelas secara mandiri.

Setelah membuat rancangan produk, dibuatlah komik dengan proses pembuatan meliputi penetapan bentuk media komik, pembuatan storyline dan script, pembuatan gambar, lattering (pengisian teks), penyusunan dan finishing.

3. Tahap Pengembangan Produk meliputi validasi oleh ahli materi dan ahli media

a) Penilaian ahli materi pada aspek kualitas materi memperoleh skor 4,59 termasuk dalam kategori sangat layak dan aspek kemanfaatan memperoleh skor 4,5 termasuk dalam kategori sangat layak. Total rata-rata skor oleh ahli materi sebesar 4,55 terletak pada interval skor $X>4,2$ yang berarti penilaian materi oleh 
ahli materi pada kelayakan materi memperoleh nilai "A" dengan kategori "Sangat Layak."

b) Penilaian media oleh ahli media dari aspek desain sampul buku memperoleh skor 4,67 termasuk dalam kategori sangat layak, aspek tata letak isi memperoleh skor 4,33 termasuk dalam kategori sangat layak, aspek tipografi memperoleh skor 4,4 termasuk dalam kategori sangat layak, dan aspek ilustrasi memperoleh skor 4,2 termasuk dalam kategori sangat layak. Total rata-rata skor oleh ahli media sebesar 4,4 terletak pada interval skor $X>4,2$ yang berarti penilaian media oleh ahli media pada kelayakan media memperoleh nilai "A" dengan kategori "Sangat Layak."

4. Tahap terakhir dari pengembangan yaitu revisi produk sesuai saran para ahli yaitu:

a) Revisi ahli materi yaitu penambahan kompetensi dasar dan kompetensi inti pada media komik Akuntansi.

Penambahan penjelasan pada awal pertemuan mengenai materi yang akan disampaikan pada pelajaran Akuntansi

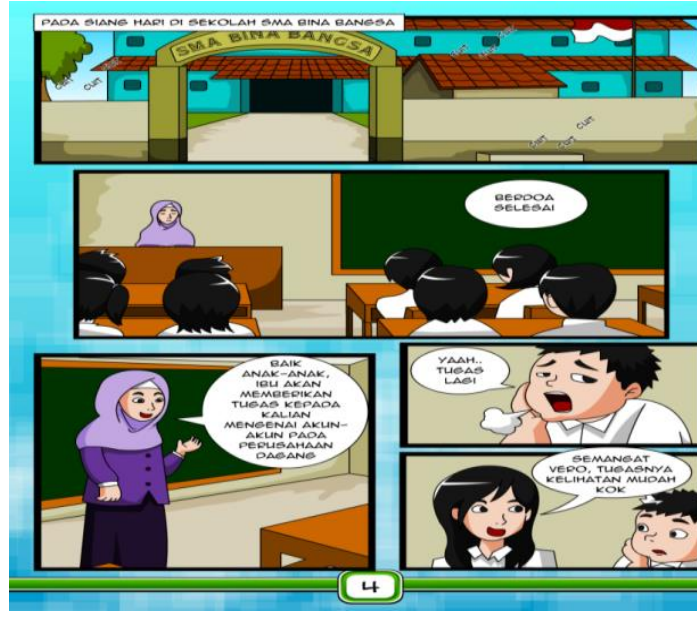

Gambar 1. Sebelum Revisi

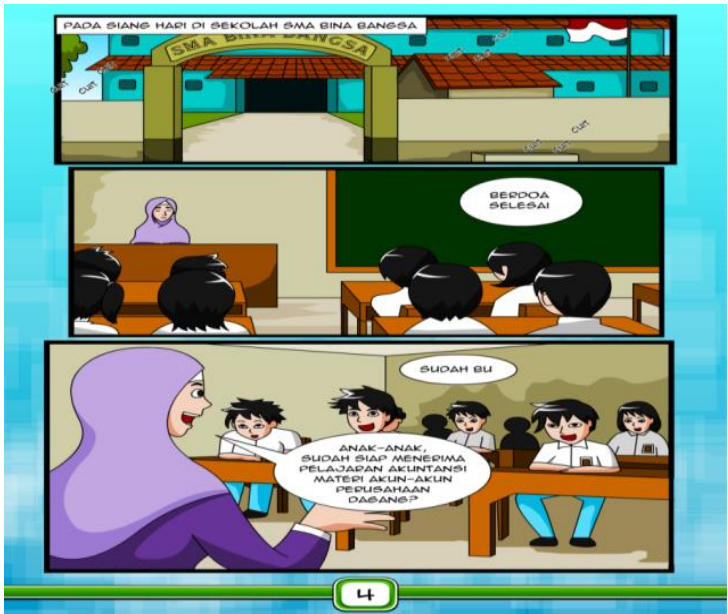

Gambar 2. Setelah Revisi

Penambahan materi tentang pengertian perusahaan dagang

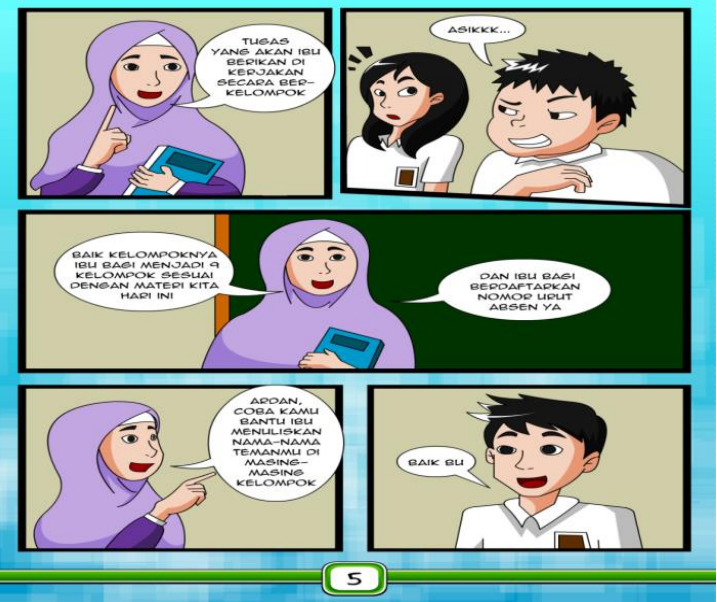

Gambar 3. Sebelum Revisi

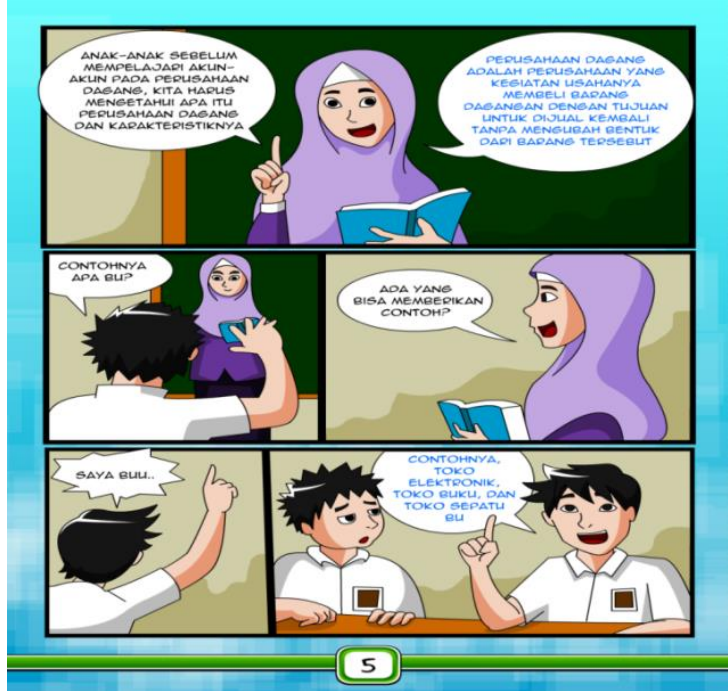

Gambar 4. Setelah Revisi 
Jurnal Pendidikan Akuntansi Indonesia, Vol. XIII, No.2, Tahun 2015

Fidya Rizka Anggraeni \& Sumarsih

$14-22$

b) Revisi ahli media antara lain:

Perubahan bentuk tulisan komik pada halaman sampul

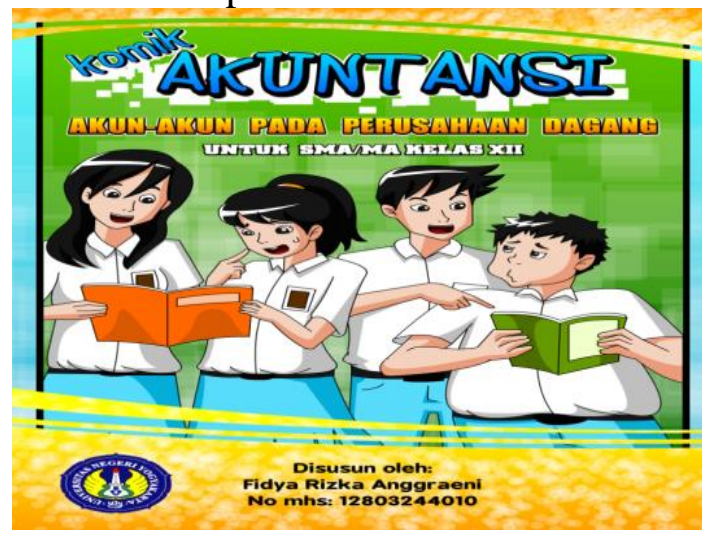

$\begin{array}{ll}\text { Gambar 5. } & \text { Halaman Sampul } \\ \text { Sebelum Revisi }\end{array}$

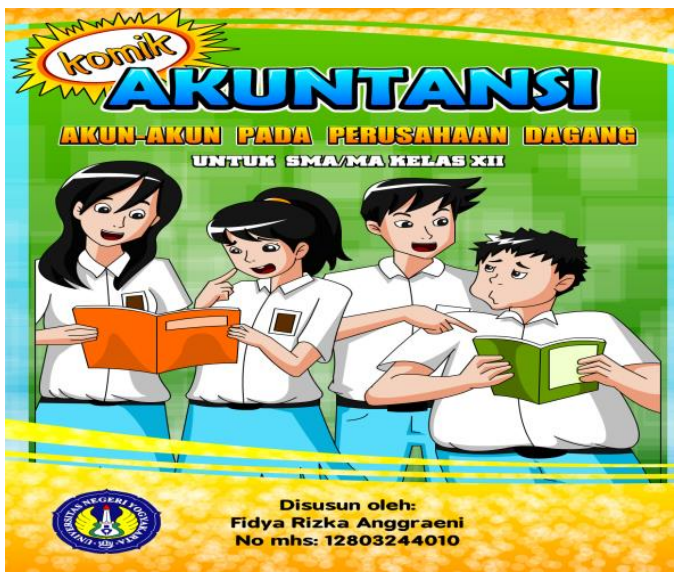

Gambar 6. Halaman Sampul

Komik Setelah Revisi

Penambahan narasi untuk memperjelas ilustrasi gambar

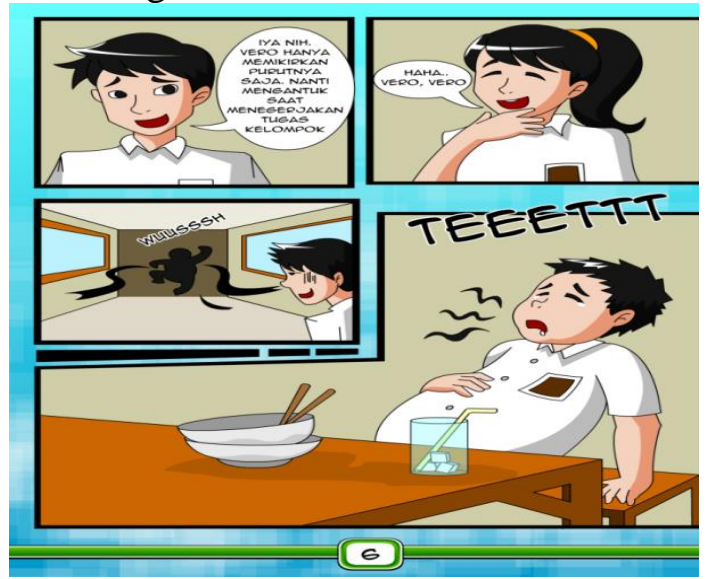

Gambar 7. Sebelum Direvisi

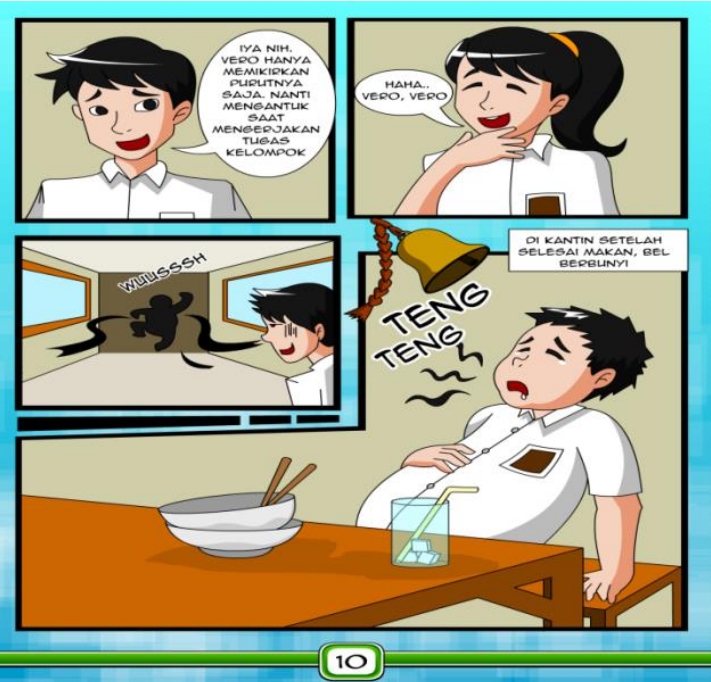

Gambar 8. Sesudah Direvisi

Pewarnaan tulisan pada materi dibedakan dengan dialog lain

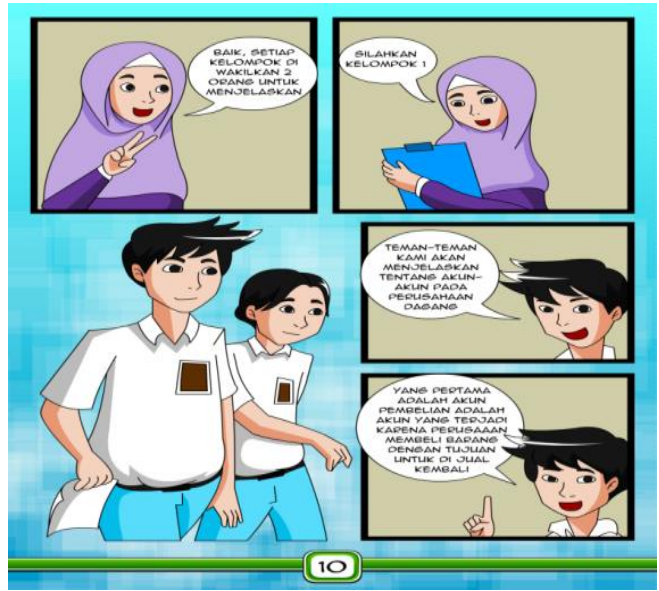

Gambar 9. Sebelum Direvisi

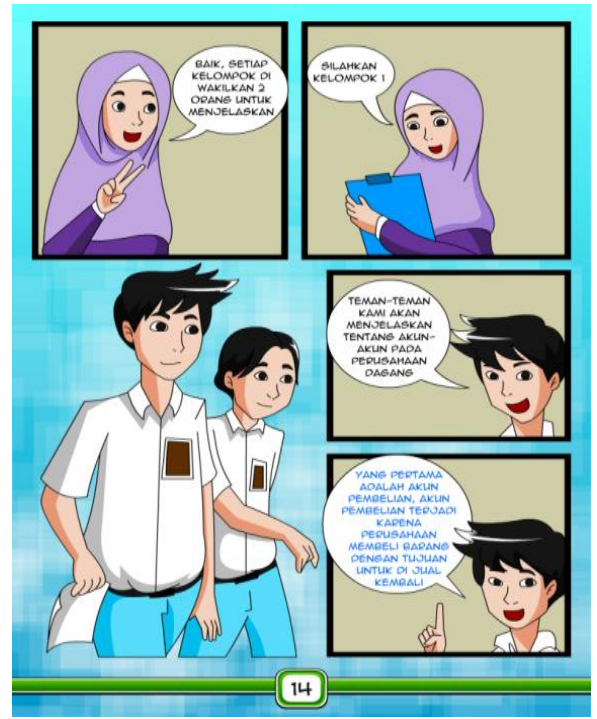

Gambar 10. Setelah Direvisi 
c. Uji Coba Siswa SMA

Penilaian siswa SMA pada aspek penyajian memperoleh skor 4,3 termasuk dalam kategori sangat layak dan aspek kemanfaatan memperoleh skor 4,34 termasuk dalam kategori sangat layak. Total rata-rata skor hasil uji coba siswa sebesar 4,32 terletak pada interval skor $\mathrm{X}>4,2$ yang berarti penilaian materi oleh ahli materi pada kelayakan materi memperoleh nilai "A" dengan kategori "Sangat Layak."

\section{Tahap Penyebaran}

Tahap terakhir dalam penelitian ini adalah tahap penyebaran. Tujuannya agar media komik yang telah dikembangkan dapat dimanfaatkan secara lebih luas. Karena adanya keterbatasan, maka penyebaran hanya dilakukan di SMA Negeri 1 Sedayu. Penyebaran komik Akuntansi hanya sebatas pada kepala sekolah, bagian kurikulum, perpustakaan sekolah, guru Akuntansi, dan siswa kelas XII IPS 3.

\section{SIMPULAN DAN SARAN}

\section{Simpulan}

Berdasarkan penelitian dan pembahasan, maka dapat disimpulkan bahwa:

1. Pengembangan media pembelajaran Akuntansi berbentuk komik pada materi akun-akun pada perusahaan dagang untuk siswa SMA Negeri 1 Sedayu kelas XII IPS 3dapat digunakan sebagai media pembelajaran. Pengembangan komik melalui empat tahap yaitu define (pendefinisian), design (perancangan), develop (pengembangan) dan disseminate (penyebaran).

2. Kelayakan komik Akuntansi yang dikembangkan berdasarkan penilaian oleh ahli materi memperoleh rata-rata skor 4,55 dari rentan 1-5 ditinjau dari aspek kualitas materi dan kemanfaatan termasuk dalam kategori sangat layak. Penilaian oleh ahli media memperoleh rata-rata 4,4 dari rentan 1-5 ditinjau dari aspek desain sampul, tata letak isi, tipografi, ilustrasi termasuk dalam kategori sangat layak. Penilaian kelayakan komik berdasarkan uji coba pada siswa SMA memperoleh skor ratarata 4,32 dari rentan 1-5 ditinjau dari aspek penyajian dan kemanfaatan termasuk dalam kategori sangat layak.

\section{Saran}

Berdasarkan kesimpulan di atas, peneliti memberikan beberapa saran antara lain:

\section{Bagi Guru}

Guru sebaiknya menerapkan media komik tersebut sebagai variasi media pembelajaran dalam kelas. Guru diharapkan pula turut menularkan penggunaan media komik dalam pembelajaran kepada guru-guru lain agar media dapat digunakan secara lebih luas.

2. Bagi Siswa

Siswa hendaknya membaca media komik yang dikembangkan untuk meningkatkan pemahaman materi tentang Akun-akun pada perusahaan dagang.

3. Bagi Peneliti Lebih Lanjut

Perlu dilakukan penelitian lebih lanjut untuk mengetahui keefektifan media komik "Akun-akun pada perusahaan dagang". Peneliti selanjutnya juga dapat 
mengembangkan media komik untuk materi yang lain.

\section{DAFTAR PUSTAKA}

Eko Putro Widoyoko. (2009). Evaluasi Program Pembelajaran. Yogyakarta: Pustaka Belajar.

Endang Mulyatiningsih. (2012). Metode Penelitian Terapan Bidang Pendidikan. Bandung: Alfabeta

Sugiyono. (2015). Metode Penelitian Kuantitatif Kualitatif \& RnD. Bandung: Alfabeta. 